Review of

ECONOMICS

and

INSTITUTIONS
Review of Economics and Institutions

ISSN 2038-1379 DOI 10.5202/rei.v6i1.172

Vol. 6 - No. 1, Winter-Spring 2015 - Article 4

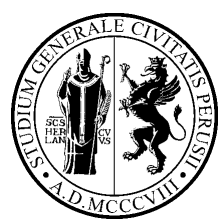

www.rei.unipg.it

\title{
Whether and How Network Structure Shapes the Value of Firm Capabilities?
}

\author{
Ishtiaq Pasha Mahmood ${ }^{\varpi}$ \\ National University of Singapore \\ Business School
}

\author{
Hongjin Zhu \\ DeGroote School of Business \\ McMaster Univerisity
}

\begin{abstract}
This study examines how firm performance is driven jointly by individual firmspecific capabilities and the characteristics of networks in which firms are embedded. By using business groups in emerging economies as the organizational lens and adopting stochastic frontier estimation to measure firm capabilities, we find that the value of a firm's capability is contingent upon the structure and the content of the intra-group network in which it is embedded. Specifically, we find that a dense intra-group network is likely to make innovative capability more valuable, although this effect varies across different types of network ties. While a dense network of intra-group buyer-supplier ties and equity ties enhances the value of innovative capability, a dense network of intragroup directorship ties does not influence the efficacy of a firm's innovative capability.
\end{abstract}

JEL classification: D21, M16, L25, O32

Keywords: business group, capability, interfirm network, Taiwan

\footnotetext{
Corresponding author. Address: National University of Singapore Business School, 15
} Kent Ridge Drive, Singapore 119245 (Phone: +65 6516-6387. Email: bizipm@nus.edu.sg).

\section{Recommended Citation}

Mahmood, I.P., Zhu, H. (2015). Whether and How Network Structure Shapes the Value of Firm Capabilities? Review of Economics and Institutions, 6(1), Article 4. doi: 10.5202/rei.v6i1.172. Retrieved from http://www.rei.unipg.it/rei/article/view/172 


\section{Whether and How Network Structure Shapes the Value of Firm Capabilities?}

While some management scholars have argued that performance differences between firms are due to their differing levels of organizational capabilities (Wernerfelt 1984; Barney, 1991; Peteraf, 1993), social network researchers have posited that performance differences stem from differences in the structural attributes of the networks in which individual firms are embedded (Granovetter, 1985; Burt, 1992; Gulati, 1999; McEvily and Marcus, 2005). For example, dense networks, in which firms are connected to each other by a thick web of relations, are seen by some scholars as being the most favorable type of network for firms that are part of such networks (Coleman, 1990). At the same time, however, others have argued that dense network structures have a negative impact on firm performance (Burt, 2000). Despite a growing consensus that both firm capabilities and network ties have significant implications for firm performance, we know little about the effect of network structures on the efficacy of firm capabilities, as well as whether and how this effect varies across different types of network ties. This study aims to fill this theoretical gap. Specifically, we examine how the overall connectivity of firms within their social networks impacts the value of their capabilities.

We use business groups in emerging economies as the organizational lens to examine how a firm's performance is driven by the interaction between its capabilities as well as the structure of the network in which it belongs. Business groups are a common organizational form across many developing and some developed economies. Sociologists often view business groups as networks that have clear boundaries and whose member firms are affiliated to each other via various formal and informal means (Granovetter, 1995) 1 Individual affiliates within a group are legally independent firms, implying that their performance is driven by their firm-specific capabilities. At the same time, however, their membership in a business group suggests that their performance is also partly determined by the structure of their group, as well as the type of intra-group ties that exist in their group. Despite growing interest in business groups among researchers, the networkspecific contingencies under which groups influence their affiliates' performance remains under-studied. We examine how the variation in affiliate performance across groups is driven jointly by group-level network structure and affiliate-level capability. The potential interactions between network structures and firm capabilities warrant cross-level analyses of affiliate performance.

In this study, we focus on a specific type of firm capability, namely, inno-

${ }^{1}$ We use the word firm and affiliate interchangeably throughout the paper. For a more detailed discussion on business groups, please see pages 8 and 9 . 
vative capability. Firms with superior innovative capability create value by detecting valuable new information, assimilating it, and successfully applying it (Eisenhardt and Martin, 2000). Moreover, interorganizational ties play a key role in innovation-creating activities (Gulati, 1999; Ahuja, 2000), making innovative capability an ideal choice to explore the relationship between group networks and firm capabilities.

Following Stochastic Frontier Estimation (SFE), we view a firm's innovative capability as the technical efficiency with which it uses the resources or inputs, such as R\&D expenditures, at its disposal to achieve certain outputs, such as patents (Dutta et al., 2005). While the use of the input-output approach to capability is relatively new in strategic management research, this approach to operationalizing firm innovative capability captures the notion of capability as a firm's ability to efficiently combine a number of resources to attain a certain goal (Amit and Schoemaker, 1993). It is also consistent with the view that capabilities are intermediate goods that help improve the productivity of a firm's resources (Makadok, 2001).

The empirical setting of this study consists of 63 affiliates that belong to 50 business groups in Taiwan between 1990 and 1998. The high level of heterogeneity across business groups, in terms of the level of overall connectivity between the affiliates within a group, makes Taiwan an interesting setting. Our results suggest that while both firm-level capability and grouplevel network structure influence affiliates' performance, the former is more valuable in groups with a dense network of ties. More interestingly, we find that this complementarity between firm capability and group network is contingent on the types of network ties: the impact of innovative capability on firm performance is enhanced in the presence of buyer-supplier ties and equity ties, but not directorship ties.

\section{Background}

This study draws from the literature on firm capabilities and networks. While resources are productive factors controlled by a firm (Barney, 1991), capabilities are the ability of firms to deploy those productive factors to attain a desired goal (Amit and Shoemaker, 1993). Thus, a capability is the ability to transform resources into economic rents. Although superior resources per se bestow great advantages upon a firm, what is more important for the firm is its ability to use those resources to continuously generate superior rents (Dutta et al., 1999). A firm with superior capabilities enjoys a competitive advantage, and this competitive advantage is sustained if these capabilities are organizationally embedded, firm-specific, and thus hard to transfer or copy across firms (Treacy and Wiersema, 1993; Peteraf, 1993).

While the capability literature (Teece and Pisano, 1994) states that a firm's performance is driven by its capabilities, it does not tell us how the effects of capabilities may be shaped by the structure and content of a firm's network 
relations. As individual firms increasingly become nodes in webs of formal and informal relationships with other firms, three questions arise as to how network ties influence the benefits of a firm's own capabilities. First, are individual firm capabilities still relevant when a firm can rely on the resources and capabilities of its network partners? Second, do network ties affect the efficacy of firm capabilities by either complementing or diminishing them? If network ties do influence the impact of firm capabilities on firm performance, a subsequent question is whether this impact differs across distinct types of ties.

In theory, network relations can strengthen as well as diminish the benefits of individual firm capabilities by affecting the firm's access to the knowledge and resources needed to exploit its capabilities. For example, certain capabilities, such as those related to new product development, are more beneficial to firms when networks provide access to complementary resources and information that facilitate successful commercialization (Ahuja, 2000). At the same time, however, having too many inter-organizational ties can reduce the value of a firm's capabilities by promoting insularity, information leakage, and free riding (Uzzi, 1997; Burt, 2000). Thus, to the extent that a firm is embedded in a network of formal and informal ties, the structure of the network is likely to shape the effectiveness of its capabilities.

Prior studies have shed some light on the role of network structure in shaping the value of capabilities. Tsai (2001) found that firms with high absorptive capacity enjoy better performance if they occupy central positions in a network. Zaheer and Bell's study (2005) indicated that a superior network position, in the form of access to structural holes, enhances a firm's performance as it enables the firm to better exploit its innovative capabilities. These studies have mainly focused on the impact of a firm's embeddedness in a network of formal and informal relationships on the exploitation of its capabilities.

However, relatively little is known about whether these effects differ across different types of ties. Firms are embedded in networks formed by a variety of ties, such as interlocking directorships, trade association memberships, and R\&D collaborations. Different types of network ties differ in the material and immaterial substances transferred through them (Podolny and Baron, 1997). They also have distinct impacts on the behaviors and interactions that characterize inter-firm relationships (Gulati and Westphal, 1999), and thus have different performance implications. To obtain a more finegrained understanding of the mechanisms through which networks influence firm performance, both independently and jointly with firms' internal capabilities, it is important to consider the role of "network content", i.e. the type of ties prevalent in a network.

Rather than regarding all types of ties as equally beneficial to firm performance, we examine the effects of three different types of intra-group ties on the efficacy of innovative capability. These ties are: buyer-supplier ties, 
equity ties, and directorship ties. Buyer-supplier ties are created when affiliates within a group interact as buyers and suppliers. Equity ties exist when affiliates own equity stakes in each other through cross-shareholdings. Directorship ties arise when individuals sit on the boards of multiple affiliates.

Besides examining the impact of different types of ties, we also shift the level of analysis from the ego-network to the overall network. This complements previous research that focused on the performance implications of the ego-network structure, and hopefully, will shed light on the understudied role of the overall structure of the network in shaping the efficacy of firm capabilities. In particular, we consider how the overall connectivity between firms within a network shapes the value of firm capability, after controlling for the effect of the network position of individual firms. To capture overall network connectivity, we adopt the concept of network density, defined as the ratio of the actual number of ties among firms within the network to the total number of potential ties in that network. A highly dense network makes it easier for network participants to leverage each others' resources (Coleman, 1988). It also induces bounded solidarity, stronger norms about reciprocity, greater trust, and sanctions against opportunistic behavior, thus facilitating knowledge transfer within the network (Granovetter, 1985; Coleman, 1990). Excessive density, however, may constrain network members' access to ideas and resources available beyond the network (Uzzi, 1997). In the absence of access to innovative ideas from outside the network, the information available through network ties tends to be homogenous and redundant and works to impede firm performance (Burt, 1992).

We investigate the contingent effect of network ties by analyzing how the density of different types of network ties affects the value of firm capabilities. We speculate that some types of network ties will enhance the value of firm capabilities, while others may not.

\section{Business Groups: A Type of Network}

A business group is a common type of multi-business firm in developing economies, frequently dominating a substantial fraction of a country's productive assets and influencing its technological development (Amsden and Hikino, 1994; Granovetter, 1995). Although definitions vary across countries, business groups generally combine elements of conglomerate holding companies and multidivisional corporations, creating a multi-business firm that has been referred to as a network form of organization (Nohria and Eccles, 1992). Like conglomerates, business groups provide a corporate financial structure that controls businesses in multiple industries (Williamson, 1985). They are also similar to multidivisional corporations in that the businesses within a business group operate with a substantial degree of interdependence.

However, business groups are also unique in some ways. They are more 
stable and coordinated than conglomerates, but are less centralized than their typical multidivisional counterparts (Granovetter, 1995). In this study, we define business groups as networks of loosely coupled legally independent firms, linked by long-standing formal and informal ties.

As a network of legally independent affiliates, the performance of each individual affiliate is influenced by its individual capabilities. However, individual affiliates can also rely on other affiliates within the same group for resources and information, implying that the performance of affiliates will also be influenced by their network relations with other group members. While both group-level network structure and affiliate-level capabilities independently affect affiliate performance, the potential interactions between network structure and firm capabilities warrant a multi-level analyses of how these two factors jointly shape affiliates' performance. Moreover, group affiliates usually maintain various types of network ties, enabling us to explore how different types of network ties influence the impact of innovative capability on performance in different ways.

In what follows, we develop two hypotheses to explore how business groups would affect firm performance by shaping the efficacy of their innovative capability. We first examine whether business groups influence the relationship between affiliates' innovative capability and their performance. Next, we investigate how distinct types of intra-group ties shape the value of innovative capability.

\section{Hypotheses}

\subsection{Network Ties Shape the Benefits of Capability}

A firm requires expertise in a set of complementary activities to exploit its innovative capability. These activities include searching for the new ideas, information and resources that constitute the material basis for innovative activities, and an ability to recombine these new ideas and resources with existing ideas and resources - a process which needs creativity, cooperation, and coordination.

The networks literature suggests that the degree of connectivity between network partners significantly affects the exploitation of the focal firm's innovative capability. There are two opposing viewpoints on the network form that is the most beneficial: Burt (1992) advocates networks rich in structural holes, while Coleman $(1988,1990)$ supports dense networks where partners are closely tied to each other. Burt (1992) argues that the network ties of a set of firms are redundant if they lead to the same members in the network, since that implies that the firms share similar sources of ideas and resources. In contrast, firms on either side of a structural hole will not have any overlapping network ties. Thus, if they connect to each other, they 
would be able to access diverse flows of ideas and resources (Hargadon and Sutton, 1997). Therefore, maximizing the presence of structural holes may produce efficient and information-rich networks beneficial to the focal firm (Burt, 1992). By connecting to mutually unconnected partners, the focal firm benefit from accessing unique ideas and resources from remote partners, and hearing about potential threats and opportunities in advance (Powell and Smith-Doerr, 1994). The advantages provided by structural holes are particularly valuable in terms of enhancing the value of the focal affiliate's innovative capability, because innovativeness is indispensable from novel ideas and abundant resources.

On the contrary, Coleman $(1988,1990)$ argues that the focal firm may benefit more from dense networks, as they are characterized by efficient resource sharing, enhanced trust and reduced opportunism. When firms are closely connected with each other, ideas and resources pooled within the network can freely flow among them. Firms are likely to trust each other because their intensive interaction allows them to observe others' actions, which in turn facilitates resource-sharing, knowledge combination, joint problem-solving and large relationship-specific investments (Zaheer and Venkatraman, 1995; Dyer and Noboeka, 2000). Moreover, they may develop shared routines of behavior and sanctions against opportunism, which enhance mutual understanding, cooperation and reciprocity, and finally lead to more productive collaboration (Uzzi, 1997; Gulati, 1999). Network closure may promote the exploitation of innovative capability by facilitating the recombination of new ideas and resources.

Considering the features of emerging economies where business groups operate, we argue that a dense group network is more likely to enhance the efficacy of affiliates' innovative capability, and thus achieve higher profitability. Emerging economies suffer from a relative lack of resources for affiliates to acquire, as well as underdeveloped infrastructure for arms-length relationships to facilitate the exchange of information and resources. Therefore, the pooling of crucial resources and the efficient internal coordination provided by business groups are crucial for enhancing affiliates' performance. In particular, to the extent that business groups are important importers of advanced technologies, they may provide access to frontiers of technology that are usually unavailable beyond the group in emerging economies. Moreover, business groups are able to establish external linkages with innovative corporations from developed countries because of their better reputation (Khanna and Palepu, 1997), providing opportunities for group members to learn how to recombine resources more efficiently and creatively. Therefore, in emerging economies characterized by scant resources and underdeveloped institutions, the potential search benefits of networks rich in structural holes are difficult to realize. Dense networks are more likely to enhance the efficacy of a firm's innovative capability by facilitating the collection of information and resources within the group, and 
the recombination of resources and ideas. Hence, we propose the following hypothesis:

Hypothesis 1: The relationship between a focal affiliate's innovative capability and its performance is moderated by the density of the intra-group network in which it is embedded, with innovative capability becoming more valuable when the density of the intra-group network increases.

\subsection{The Moderating Effects of Network Ties: Tie-Content as a Contingency}

Although network ties may facilitate the exploitation of innovative capability, the relative benefits may vary across different types of ties because of differences in the content of ties.

Group-wide buyer-supplier ties can enhance the value of the focal affiliate's innovative capability by providing earlier access to information about consumers' potential demand. Firms with superior innovative capability are likely to make better use of this information advantage to develop new products in response to these opportunities (Cohen and Levinthal, 1990). Moreover, affiliates in a network replete with buyer-supplier ties are exposed to novel and diverse ideas from customers and suppliers (von Hippel, 1989; Teece, 1989), as the intensive interconnections facilitate fast and efficient flows of information (Gnyawali and Madhavan, 2001). Nevertheless, the external knowledge acquired will not be beneficial unless the affiliates are equipped with strong innovative capabilities, since successful innovation requires the ability to recombine existing information and known knowledge into novel solutions (Nahapiet and Ghoshal, 1998; Fleming, 2001). The theoretical models of innovation inspired by recent advances in newgrowth theory in economics point out that the degree of innovation attained by any single firm is related not only to its ability to obtain sufficient resources, but also to its ability to recombine its own and external ideas into new concepts (Weitzman, 1998). Affiliates which possess superior a innovative capability and are embedded in a dense network of buyer-supplier ties are expected to be able to better absorb, recombine and utilize the quick, novel, and diverse knowledge provided by the dense network and successfully come up with timing innovations.

At the same time, dense buyer-supplier ties can also undermine the exploitation of affiliates' innovative capability by making them insular. Extensive internal ties might cause affiliates to focus internally, rather than search the external environment for new ideas, thus limiting opportunities for innovation (Nelson and Winter, 1982). However, we expect that the positive effects of intensive buyer-supplier ties on innovative capability will offset the negative effects for two key reasons. First, as indicated above, affiliates with a strong innovative capability are better able to take advantage of 
knowledge passing through their buyer-supplier ties. Second, affiliates with high levels of innovative capability are less likely to suffer from the negative effect of closed dense networks, relative to their less capable counterparts. Capable affiliates which possess innovation-friendly organizational routines, efficient communication systems, and innovative professionals are more likely to come up with novel ideas internally and be less dependent upon the external sources of new ideas. Therefore, innovative affiliates in dense networks of buyer-supplier ties will enhance performance by better exploiting their innovative capabilities.

Exploiting innovative capability also requires sufficient capital to support trial-and-error innovation procedures. In emerging economies, where many of the institutions that underpin the functions of a well-developed capital market either do not exist or exist in relatively weak form, equity ties among group affiliates provide access to internal capital markets and credibility. This makes it easier for an affiliate to access complementary resources from other affiliates. Such ties are of particular importance in emerging economies where there are scant capital resources available beyond business groups (Chang and Hong, 2000). Therefore, affiliates with more equity ties with other affiliates are more likely to enhance the value of their own innovative capability, compare to those with fewer equity ties.

The final type of intra-group ties, directorship ties, is likely to devaluate an affiliate's innovative capability through several paths. First of all, the highly concentrated authority among a few directors renders them information-overloaded. Since it has been shown that decision-makers are limited in their ability to process the received information when its amount exceeds what they can process (Van Zandt, 2004), directors who sit on many boards of a group's affiliates are unable to disseminate useful information across affiliates in time. Given the importance of efficient information flow and the diffusion of new knowledge for innovation, the innovative activities of affiliates would be negatively affected by the problem of information overload.

Furthermore, many business groups in emerging economies are familycontrolled such that family members often hold the position of board chairs of multiple affiliates. Family directors are loath to hire capable outside professionals and invest in projects that require external support due to their lack of trust in outsiders and an excessive desire to control the whole group (Fukuyama, 1995; La Porta, et al., 1997; Morck and Yeung, 2004). Since human resource plays a key role in knowledge-creation processes, the shortage of professionals would greatly undermine the innovativeness of affiliates. Finally, in order to maximize the profits of the entire group, the central family may use the internal capital market to subsidize poorly performing affiliates. This practice, called tunneling, deprives focal affiliates of the financial capital needed for innovative activities. In addition, since innovation may destroy the value of wealth possessed by family members, family directors would favor the status quo and will tend to spend less on inno- 
vation to prevent Schumpeter's (1934) creative destruction from becoming "creative self-destruction".

However, notwithstanding their potential negative effects on affiliates' innovative capability, it is possible that directorship ties may actually promote innovative activities by facilitating internal coordination and reducing transaction costs through frequent communications among directors and family authorities (Hamilton, 1997; Chung, 2003). Nonetheless, we argue that the negative consequences of family control on innovative capability dominate for two reasons. First, affiliates that are capable of innovation will be constrained by the inefficient information flow, lack of capable professionals, and deprivation of financial capital necessary for innovation. These limitations will paralyze innovative activities and hence diminish the value of innovative capability. Second, innovative affiliates are less likely to obtain significant benefits from the enhanced internal coordination and reduced transaction costs brought about by directorship ties because of the efficiencies of their existing routines and structures (Eisenhardt and Martin, 2000).

In sum, considering the heterogeneity in the content of intra-group network ties, we propose the following hypothesis:

Hypothesis 2: Different types of network ties moderate the relationship between an affiliate's innovative capability and its performance to different degrees: buyer-supplier ties and equity ties enhance the value of innovative capability, while directorship ties reduce its value.

\section{Data and Measures}

We use Taiwan as the empirical setting for testing the hypotheses. While Taiwan is famous for its small and medium sized enterprises, business groups are also important players in its corporate landscape (Hamilton and Biggart, 1988; Hamilton and Kao, 1990). Taiwan is an ideal setting for at least three additional reasons: First, business group affiliated firms in Taiwan have played important roles as innovators during a period in which Taiwan moved from being primarily an imitator to becoming an important source of innovation during the 1990s (Hobday, 1995). Between 1990 and 1999, business group affiliates received roughly $40 \%$ of the US patents awarded to Taiwanese enterprises. While affiliates such as United Microelectronic Corporation (UMC group), Taiwan Semiconductor Manufacturing Company (TSMC group), Winbond Electronics (Walsin Lihua group), and Hon Hai Precision Industry Company (Hon Hai Group) have been successful as innovators, the variation in financial performance across affiliates with similar levels of innovativeness but different group affiliations makes Taiwan especially intriguing for examining the interface between intra-group network ties and affiliate capability.

Second, business groups in Taiwan are heterogeneous: they are formed 
via a rich variety of network ties, and their financial performance varies significantly both within and across the groups. The ties that connect group affiliates in Taiwan range from informal ties based on family, friendship, religion, language, and ethnicity (Khanna and Rivkin, 2001; Luo and Chung, 2005) to formal economic arrangements such as equity cross-holdings, direct interlocks, and buyer-supplier agreements (Lincoln et al., 1996). In this study, we examine the effect of three types of the most important and prevalent intra-group ties: buyer-supplier ties, equity ties, and directorship ties. The variation across groups in terms of pattern of ties makes Taiwan particularly attractive for our study.

Third, business group membership is clearly defined in Taiwan. This is in contrast to other countries, where the ambiguity of group boundaries makes it difficult to examine the effects of group attributes on affiliates' performance. In Japan, for instance, a lack of family solidarity and governmental encouragement of inter-group activities obscures the boundaries of the keiretsu (Saxonhouse, 1993; Weinstein and Yafeh, 1995). In Taiwan, by contrast, cultural norms, such as patrilineal family connections and regional kinship, enable group boundaries to be clearly delineated (Numazaki, 1986). Owners and directors of group affiliates in Taiwan can be easily identified, along with detailed data on operating, directorship, and investment ties. Thus, the preponderance of business groups in Taiwan, together with the heterogeneity of their network ties and the ease of identifying group affiliation, allows us to test fairly easily when and how business groups create value for their affiliates.

\subsection{Data and Sample}

To test our hypotheses, we need business group-level data on the network ties between group affiliates, and firm-level data on firms' innovative capability and performance. We refer to three data sources to obtain these measures. Our major data source is the Business Groups in Taiwan (BGT) directory, compiled by China Credit Information Service (CCIS) in Taipei. CCIS is the oldest and most prestigious credit-checking agency in Taiwan and is affiliated to Standard and Poor's in the United States. The BGT directory is the most comprehensive and reliable source for business groups in Taiwan. It contains information on the top 100 business groups (ranked by turnover) and is confined to groups whose principal firms are registered in Taiwan. CCIS defines a business group as "a coherent business organization including several independent enterprises." CCIS constructs its database by examining inter-organizational relationships such as the presence of a shared identity, cross-shareholdings, and interlocking directorships.

According to BGT, the top 100 groups contributed $42 \%$ of national GDP in the 1990s, indicating that they have a significant impact on business activity within Taiwan. While several previous studies have relied on this 
source (Hamilton and Biggart, 1988; Claessens et al., Lang 2000; Khanna and Rivkin, 2001), no prior research has translated and coded the data on intra-group ties. This was obtained by collating the data on each group's intra-group buyer-supplier relationships, equity cross-holdings, and shared directorships. The BGT database also provides demographic information on business groups (e.g. group age, size, performance, and liability) and their affiliates (e.g. firm age and size). When coding the data, we read the BGT directories of 1990, 1994, and 1998, identified groups and affiliates, and manually transcribed information about each group and its affiliates.

Measuring firm innovative capability and performance requires detailed information, which is only available for publicly listed firms in Taiwan. Therefore, the list of focal firms was confined to affiliate firms that were listed on Taiwan's Stock Market ${ }^{2}$. Innovative capability was measured by examining each firm's R\&D expenditure, obtained from the Taiwan Economic Journal Data Bank ${ }^{3}$ (http:/ / www.tej.com.tw), and its number of successful patent applications. The latter was sourced from the online database of the Taiwanese Intellectual Property Office (http://www.patent.org.tw), which collects information on the patent applications of Taiwanese firms since 1990. Financial data was obtained from the Taiwan Economic Journal Data Bank to calculate each firm's Tobin's $q$, which was the performance measure we used. Our final sample consisted of 100 observations for 63 listed firms belonging to 47 business groups for the years of 1990,1994, and 1998. The four-year window allows sufficient variance in the focal firm's innovative capability as well as its group network structure.

Dependent Variable - Tobin's $q$ : We use Tobin's $q$ as our measure of performance. It is defined as (market value of equity + book value of preferred stock + book value of debt)/(book value of assets), where the market value of equity is calculated using closing stock prices on the last trading day of the year (Khanna and Palepu, 2000). Tobin's $q$ has been widely used in the business group literature, because of its advantages over accounting measures. It reflects the market value of the firm in a timely manner, as it is based on the evaluation of firm capabilities, which are inherently dynamic. Moreover, Tobin's $q$ is independent of a firm's scale of operation. This characteristic matches our intent to capture the contribution of firm capabilities to performance, and not the portion of performance that is attributable to a large scale of operations or resource use..$^{4}$

${ }^{2}$ For groups with more than one listed firms, we included all the listed firms in that group in our sample.

3 This database provides verified, consistent, and timely data about Taiwanese listed companies.

4 Since ROA is plagued by business cycle effects and does not account for differences in systematic risk, Tobin's Q is considered to be more reliable (Khanna and Palepu, 2000). However, we recognize that the illiquidity and disclosure problems of many emerging economy stock markets, including Taiwan's, makes the use of Tobin's Q problematic. Thus, we tested the robustness of our results by using ROA as the dependent variable, 
Independent Variables: Firm innovative capability is calculated in the way consistent with Dutta et al. (1999). Details of the estimation are provided in Appendix 1 and 2.

Four variables are used to measure the characteristics of intra-group network ties. The density of all ties is defined as the ratio of the actual to the potential number of ties within a business group. Operating density is the ratio of actual buyer-supplier ties within a business group to the total number of potential buyer-supplier ties in that group. Equity density refers to the ratio of actual equity ties within a business group to the total number of potential equity ties in that group. Finally, director density is defined as the ratio of actual directorship ties among affiliates within a business group to the total number of potential director ties in that group.

Control Variables: We included two affiliate-level variables to capture other influences on performance. Affiliate size denotes the total assets of the affiliate (thousands of New Taiwanese dollars). Large affiliates may be better positioned to acquire capabilities. Also, scale economies, in terms of spreading the costs of implementing capabilities over a large base of operations, are greater in larger affiliates. Affiliate age refer to the number of years from the establishment of the firm. Also, 19 industry categories are included to control for variance in firm performance due to industry-level variables.

To the extent that firms within a group may share certain common group specific attributes, error terms across affiliates within a group may correlate with each other. Thus, a failure to control for group-specific heterogeneities might lead to the problem of autocorrelation among affiliates within the same group. We address this problem by including three group-level variables that address group-level influences on the development of affiliate capability: group size records total group assets (in thousands of New Taiwanese dollars), group ROA refers to the annual group-level return on assets, and group liability is measured as the ratio of debt to net worth.

The centrality measure uses degree centrality, which indicates the number of direct partners with which a focal affiliate has relationships. The centrality of all ties is defined as the ratio of the number of network ties a focal affiliate maintains to the number of affiliates in its intra-group network. Operating centrality is the ratio of the number of buyer-supplier ties a focal affiliate maintains to the number of affiliates in its intra-group network. Equity centrality refers to the ratio of the number of equity ties a focal affiliate maintains to the number of affiliates in its intra-group network. Director centrality is defined as the ratio of the number of directorship ties a focal affiliate maintains to the number of affiliates in its intra-group network. We did not use other centrality measures, such as closeness centrality and betweenness centrality (Freeman, 1977), due to the small size of our networks. We created four degree centrality measures: one for each of the three types of tie and one for all types of ties. In addition, we controlled for two other firm capa-

and they remain very similar. 
bilities, namely marketing capability and manufacturing capability, in the sensitivity analysis because they influence both the efficacy of innovative capability and the performance of the affiliate (Dutta et al., 1999). Details of the estimation of the two capabilities are provided in Appendix 1 and 2.

\section{Empirical Analyses}

Our empirical analysis involves two steps. First, we estimate firm capabilities using stochastic frontier estimation (SFE). This approach views capabilities as an "intermediate transformation ability" (Dutta et al., 1999) that allows a firm to convert inputs available to the firm (i.e. its resources) into desired outputs (i.e. its objectives). We expect that firms that are efficient in deploying their resources to have superior capabilities, and thus perform better than those that are less efficient. SFE enables us to empirically estimate the efficient frontier (i.e. the desired goal) and thus the level of productive efficiency (i.e. a firm's capability) achieved by each firm in the study. Second, we explore the impact of intra-group network, firm capabilities, as well as their interactions on firm performance.

\subsection{Summary Statistics}

Table 1A shows that the number of group affiliates and listed affiliates increased over time. Operating density (based on buyer-supplier ties) dropped substantially, while director density kept rising. Operating density fell as Taiwanese business groups diversified into service sectors during this period (Amsden and Chu, 2003). The desire to preserve family control encouraged the maintenance of directorship ties.

Table 1A - Business Groups in Taiwan, 1990-1998: Affiliates, Network Density and Innovative Capability

\begin{tabular}{|c|c|c|c|c|c|c|c|c|}
\hline Year & $\begin{array}{l}\text { Number } \\
\text { of groups }\end{array}$ & $\begin{array}{l}\text { Number } \\
\text { of Group } \\
\text { Affiliates }\end{array}$ & $\begin{array}{l}\begin{array}{c}\text { Average Number } \\
\text { of }\end{array} \\
\text { Group Affiliates }\end{array}$ & $\begin{array}{c}\text { Number } \\
\text { of Listed } \\
\text { Firms }\end{array}$ & $\begin{array}{l}\text { Mean } \\
\text { operating } \\
\text { density }\end{array}$ & $\begin{array}{l}\text { Mean } \\
\text { equity } \\
\text { density }\end{array}$ & $\begin{array}{l}\text { Mean director } \\
\text { density }\end{array}$ & $\begin{array}{c}\text { Average } \\
\text { Affiliate } \\
\text { Innovative capability }\end{array}$ \\
\hline 1990 & 15 & 250 & 16.7 & 15 & 0.159 & 0.242 & 0.293 & 0.894 \\
\hline 1994 & 27 & 951 & 35.2 & 27 & 0.106 & 0.270 & 0.323 & 0.913 \\
\hline 1998 & 49 & 1598 & 32.6 & 50 & 0.080 & 0.217 & 0.338 & 0.958 \\
\hline Total & 91 & 2970 & 32.6 & 92 & 0.115 & 0.243 & 0.318 & 0.922 \\
\hline
\end{tabular}




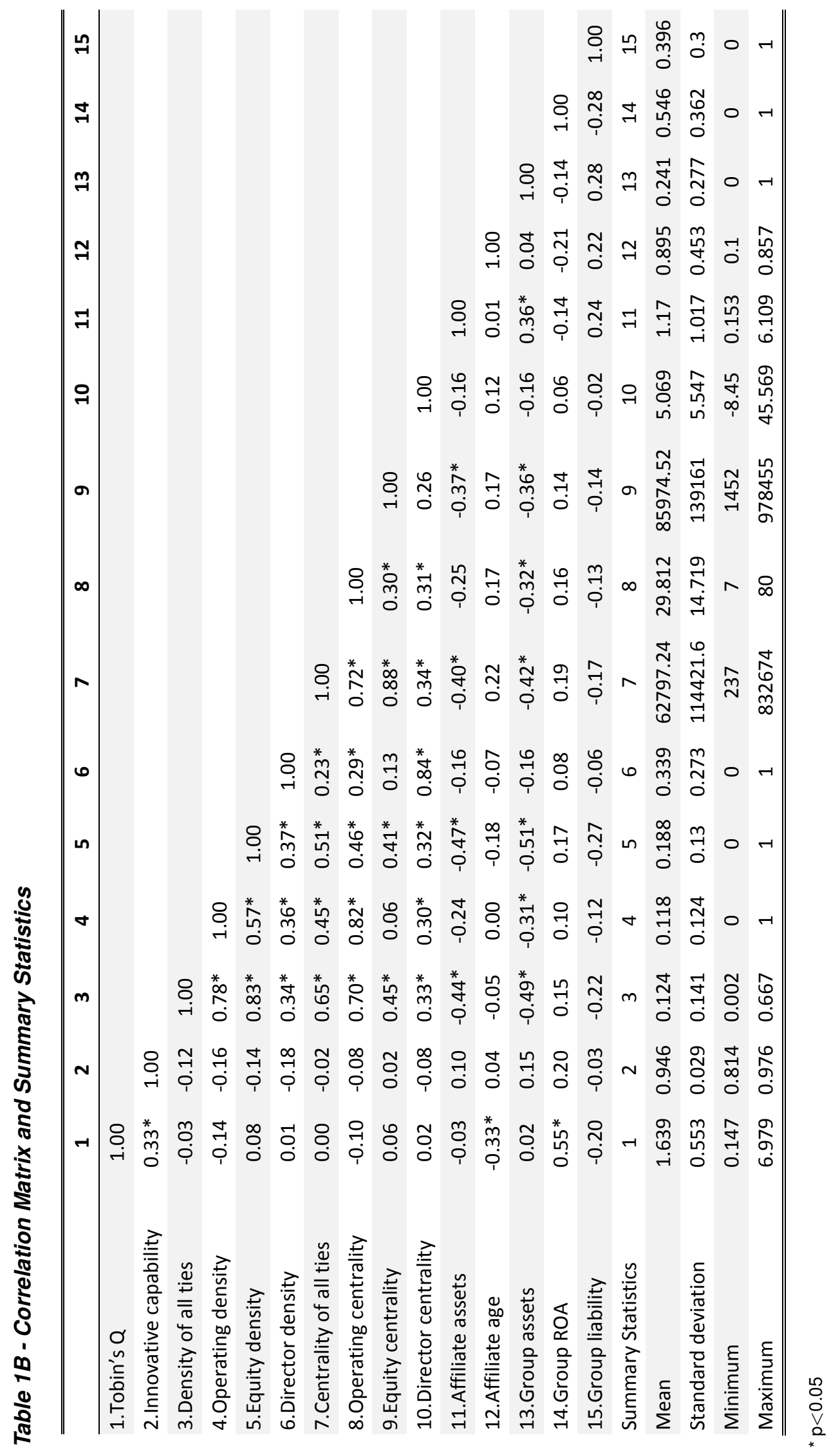


Table 1B reports the correlations between the independent and dependent variables, as well as their summary statistics. There is significant variation in affiliates' performance during the period, with the maximum value being 6.979 and the minimum 0.147 . In addition, we note that there is significant heterogeneity in innovative capability across firms in our sample, with a standard deviation of $12.9 \%$. This characteristic fits the prerequisite for capabilities to serve as sources of competitive advantage, which is that they should be heterogeneously distributed. Table 1B also indicates that the density and centrality measures of the group network are highly correlated. These suggest a need to exercise caution when putting both of them in a regression. Since the correlation of equity density and equity centrality is the lowest, we control for equity centrality in the following regressions.

\subsection{Regression Results}

Table 2 provides pooled regression results on affiliates' performance using ordinary least square (OLS) estimation and Generalized Estimating Equations (GEE) as robustness check. To the extent that firms within a group share certain group-specific attributes, error terms across firms in a group may correlate with each other. To control for the autocorrelation between affiliates of the same business group, we cluster each affiliate around its group affiliation. We tested Hypothesis 1 using three models.

Table 2 - Effects of all Types of Intra-Group Network Ties on the Tobinâs Q of Group Affiliates Using OLS and GEE

\begin{tabular}{|c|c|c|c|c|c|c|c|c|}
\hline \multirow[t]{2}{*}{ Dependent variable } & \multicolumn{4}{|c|}{$\begin{array}{c}\text { OLS } \\
\text { Tobin's Q of Affiliate }\end{array}$} & \multicolumn{4}{|c|}{$\begin{array}{c}\text { GEE } \\
\text { Tobin's Q of Affiliate }\end{array}$} \\
\hline & Model 1 & Model 2 & Model 3 & Model 4 & Model 5 & Model 6 & Model 7 & Model 8 \\
\hline \multicolumn{9}{|l|}{ Control variable } \\
\hline Innovative capability & $\begin{array}{l}6.683^{* *} \\
(2.959)\end{array}$ & $\begin{array}{c}10.973^{* * *} \\
(3.411)\end{array}$ & $\begin{array}{c}11.032^{* * *} \\
(3.455)\end{array}$ & $\begin{array}{l}5.587^{* *} \\
(2.093)\end{array}$ & $\begin{array}{c}6.974^{* * *} \\
(2.650)\end{array}$ & $\begin{array}{c}11.160 * * * \\
(2.667)\end{array}$ & $\begin{array}{c}11.195^{* * *} \\
(2.673)\end{array}$ & $\begin{array}{l}5.587^{* *} \\
(2.161)\end{array}$ \\
\hline Marketing capability & & & & $\begin{array}{c}1.655 \\
(1.321)\end{array}$ & & & & $\begin{array}{l}1.655 \\
(1.065)\end{array}$ \\
\hline Manufacturing capability & & & & $\begin{array}{c}16.706^{* * *} \\
(1.809)\end{array}$ & & & & $\begin{array}{c}16.706^{* * *} \\
(1.945)\end{array}$ \\
\hline Density of all ties & $\begin{array}{l}-0.631 \\
(0.840)\end{array}$ & $\begin{array}{l}-0.483 \\
(0.759)\end{array}$ & $\begin{array}{l}-0.635 \\
(0.873)\end{array}$ & $\begin{array}{c}0.299 \\
(0.764)\end{array}$ & $\begin{array}{l}-0.527 \\
(0.646)\end{array}$ & $\begin{array}{l}-0.357 \\
(0.599)\end{array}$ & $\begin{array}{l}-0.450 \\
(0.767)\end{array}$ & $\begin{array}{l}0.300 \\
(0.625)\end{array}$ \\
\hline Centrality of all ties & & & $\begin{array}{c}0.077 \\
(0.324)\end{array}$ & $\begin{array}{c}0.190 \\
(0.293)\end{array}$ & & & $\begin{array}{c}0.046 \\
(0.241)\end{array}$ & $\begin{array}{l}0.190 \\
(0.192)\end{array}$ \\
\hline Affiliate size (logged assets) & $\begin{array}{c}0.278 \\
(0.376)\end{array}$ & $\begin{array}{c}0.332 \\
(0.351)\end{array}$ & $\begin{array}{c}0.319 \\
(0.353)\end{array}$ & $\begin{array}{c}0.124 \\
(0.240)\end{array}$ & $\begin{array}{c}0.249 \\
(0.385)\end{array}$ & $\begin{array}{c}0.290 \\
(0.359)\end{array}$ & $\begin{array}{c}0.281 \\
(0.362)\end{array}$ & $\begin{array}{c}0.123 \\
(0.272)\end{array}$ \\
\hline Affiliate age & $\begin{array}{l}-0.010 \\
(0.006)\end{array}$ & $\begin{array}{l}-0.009^{*} \\
(0.005)\end{array}$ & $\begin{array}{l}-0.010 \\
(0.006)\end{array}$ & $\begin{array}{l}-0.004 \\
(0.004)\end{array}$ & $\begin{array}{c}-0.011^{* *} \\
(0.005)\end{array}$ & $\begin{array}{c}-0.010^{* *} \\
(0.005)\end{array}$ & $\begin{array}{c}-0.011^{* *} \\
(0.005)\end{array}$ & $\begin{array}{l}-0.005 \\
(0.005)\end{array}$ \\
\hline Group size (logged assets) & $\begin{array}{l}-0.290 \\
(0.404)\end{array}$ & $\begin{array}{l}-0.438 \\
(0.359)\end{array}$ & $\begin{array}{l}-0.422 \\
(0.364)\end{array}$ & $\begin{array}{l}-0.124 \\
(0.254)\end{array}$ & $\begin{array}{l}-0.270 \\
(0.408)\end{array}$ & $\begin{array}{l}-0.405 \\
(0.381)\end{array}$ & $\begin{array}{l}-0.394 \\
(0.385)\end{array}$ & $\begin{array}{l}-0.124 \\
(0.291)\end{array}$ \\
\hline Group return-on-assets & $\begin{array}{c}0.062^{* * *} \\
(0.023)\end{array}$ & $\begin{array}{l}0.048^{* *} \\
(0.023)\end{array}$ & $\begin{array}{l}0.047^{* *} \\
(0.021)\end{array}$ & $\begin{array}{l}0.036^{*} \\
(0.020)\end{array}$ & $\begin{array}{c}0.063 * * * \\
(0.011)\end{array}$ & $\begin{array}{c}0.049 * * * \\
(0.011)\end{array}$ & $\begin{array}{c}0.048 * * * \\
(0.011)\end{array}$ & $\begin{array}{c}0.036 * * * \\
(0.008)\end{array}$ \\
\hline $\begin{array}{l}\text { Group Liability } \\
\text { Independent variable }\end{array}$ & $\begin{array}{l}-0.073 \\
(0.083)\end{array}$ & $\begin{array}{l}-0.061 \\
(0.076)\end{array}$ & $\begin{array}{l}-0.060 \\
(0.077)\end{array}$ & $\begin{array}{c}0.017 \\
(0.058)\end{array}$ & $\begin{array}{l}-0.057 \\
(0.083)\end{array}$ & $\begin{array}{l}-0.043 \\
(0.077)\end{array}$ & $\begin{array}{l}-0.043 \\
(0.077)\end{array}$ & $\begin{array}{l}0.017 \\
(0.060)\end{array}$ \\
\hline Innovative capability*Density of all ties & & $\begin{array}{c}0.283^{* * *} \\
(0.081)\end{array}$ & $\begin{array}{c}0.284^{* * *} \\
(0.081)\end{array}$ & $\begin{array}{c}0.169 * * * \\
(0.059)\end{array}$ & & $\begin{array}{c}0.281^{* * *} \\
(0.071)\end{array}$ & $\begin{array}{c}0.282^{* * *} \\
(0.071)\end{array}$ & $\begin{array}{c}0.169 * * * \\
(0.056)\end{array}$ \\
\hline Constant & $\begin{array}{r}-4.785^{*} \\
(2.726)\end{array}$ & $\begin{array}{c}-7.905^{* *} \\
(3.178)\end{array}$ & $\begin{array}{c}-8.068^{* *} \\
(3.273)\end{array}$ & $\begin{array}{l}-21.920^{* * *} \\
(2.980)\end{array}$ & $\begin{array}{c}-4.986^{*} \\
(2.770)\end{array}$ & $\begin{array}{l}-8.020^{* * *} \\
(2.675)\end{array}$ & $\begin{array}{l}-8.116 * * * \\
(2.720)\end{array}$ & $\begin{array}{l}-21.921^{* * *} \\
(2.768)\end{array}$ \\
\hline R-square & $50.21 \%$ & $57.05 \%$ & $57.09 \%$ & $75.62 \%$ & N.A. & N.A. & N.A. & N.A. \\
\hline Number of observations & 100 & 100 & 100 & 100 & 100 & 100 & 100 & 100 \\
\hline
\end{tabular}

*** Significant at $1 \%$ level; ** significant at $5 \%$ level; * significant at $10 \%$ level. Standard errors are in the parentheses. Dummy variables for industry are included in the models, but not shown in the table.

Model 1 includes all of the control variables, and serves as the baseline model. The interaction between innovative capability and the density of all ties was included in Model 2. Consistent with our expectations, the sig- 
nificantly positive sign $(\mathrm{P}<0.01)$ on the term Innovative capability* Density of all ties implies that a firm's innovative capability positively moderates the relation between network density and firm performance. As a robustness check, we controlled for the effect of network position by adding the centrality of all ties in Model 3 and found the same result as Model 2. Therefore, Hypothesis 1, which proposes that the density of a group's network complements the performance impacts of its affiliates' innovative capabilities, is supported.

The left half of Table 3 shows the results of the five OLS models that were used to test Hypothesis 2, which posited that the complementarity of network ties to a firm's innovative capability varies across different types of ties. The first three models include three interaction terms, consisting of the interaction of innovative capability and the three types of intra-group ties, in isolation. The results indicate that buyer-supplier ties and equity ties significantly enhance the value of innovative capability, while directorship ties do not influence the relationship between innovative capability and performance. When all of the interaction terms were included (Model 4), the results remain similar, although the strength of the complementarity effect of equity density decreased. To control for the effect of network position, we included equity centrality in the model; however, the results do not change substantially. These findings suggest that Hypothesis 2 is supported.

\subsection{Sensitivity Analyses}

We undertook several sensitivity analyses. First, in addition to clustering affiliates around their group affiliations control for group-specific heterogeneity, we also clustered around each affiliate to control for correlations among firm-specific observations over time. The results were similar. Second, although we did not find a significant moderating effect of director density on the relationship between innovative capability and performance, a question arises as to whether such moderating effect may be strengthened as the level of family control increases. When accounting for family control by including the ratio of family members among directors, we found that family control reduced the value of innovative capability, which is supportive to our discussion about the role of family members sitting on boards.

Third, we addressed several alternative explanations to clarify causality. For example, affiliates' performance and group-level density could both be attributed to a third unobserved variable. It has been pointed out in the literature (Chintagunta et al., 1993) that failing to control for unobserved heterogeneity may lead to inconsistent parameter estimates. We address this problem by including a firm's marketing capability and manufacturing capability. Existing literature indicates that marketing capability and manufacturing capability may enhance both firm performance and the efficacy of the firm's innovative capability (Dutta et al., 1999). Model 4 and Model 8 
Table 3 - Effects of Specific Type of Intra-Group Network Ties on the Tobinâs Q of Group Affiliates Using OLS and GEE

\begin{tabular}{|c|c|c|c|c|c|c|c|c|c|c|}
\hline \multirow[t]{2}{*}{ Dependent variable } & \multicolumn{5}{|c|}{$\begin{array}{c}\text { OLS } \\
\text { Tobin's Q of Affiliate }\end{array}$} & \multicolumn{5}{|c|}{$\begin{array}{c}\text { GEE } \\
\text { Tobin's Q of Affiliate }\end{array}$} \\
\hline & Model 1 & Model 2 & Model 3 & Model 4 & Model 5 & Model 6 & Model 7 & Model 8 & Model 9 & Model 10 \\
\hline Innovative capability & $\begin{array}{c}11.520^{* *} \\
(4.417)\end{array}$ & $\begin{array}{c}9.904^{* *} \\
(3.871)\end{array}$ & $\begin{array}{l}7.085^{* *} \\
(3.085)\end{array}$ & $\begin{array}{c}10.748^{* *} \\
(4.643)\end{array}$ & $\begin{array}{l}7.030^{* *} \\
(3.364)\end{array}$ & $\begin{array}{c}11.458^{* * *} \\
(2.351)\end{array}$ & $\begin{array}{c}9.427 * * * \\
(2.251)\end{array}$ & $\begin{array}{c}7.498^{* * *} \\
(2.723)\end{array}$ & $\begin{array}{c}10.243^{* * *} \\
(2.250)\end{array}$ & $\begin{array}{c}7.076^{* * *} \\
(1.584)\end{array}$ \\
\hline Marketing capability & & & & & $\begin{array}{l}1.505^{*} \\
(0.818)\end{array}$ & & & & & $\begin{array}{l}1.485^{*} \\
(0.784)\end{array}$ \\
\hline Manufacturing capability & & & & & $\begin{array}{c}17.202^{* * *} \\
(2.063)\end{array}$ & & & & & $\begin{array}{c}17.182^{* * *} \\
(1.475)\end{array}$ \\
\hline Operating density & $\begin{array}{c}0.411 \\
(1.133)\end{array}$ & & & $\begin{array}{l}-0.297 \\
(1.354)\end{array}$ & $\begin{array}{c}1.612 \\
(0.988)\end{array}$ & $\begin{array}{c}0.668 \\
(0.613)\end{array}$ & & & $-0.239(0.714)$ & $\begin{array}{c}1.620^{* * *} \\
(0.495)\end{array}$ \\
\hline Equity density & & $\begin{array}{c}0.512 \\
(0.637)\end{array}$ & & $\begin{array}{l}1.451^{* *} \\
(0.630)\end{array}$ & $\begin{array}{c}0.601 \\
(0.496)\end{array}$ & & $\begin{array}{c}0.587 \\
(0.555)\end{array}$ & & $\begin{array}{l}1.547^{* *} \\
(0.752)\end{array}$ & $\begin{array}{c}0.598 \\
(0.481)\end{array}$ \\
\hline Director density & & & $\begin{array}{l}-0.203 \\
(0.286)\end{array}$ & $\begin{array}{l}-0.149 \\
(0.293)\end{array}$ & $\begin{array}{l}-0.269 \\
(0.209)\end{array}$ & & & $-0.146(0.327)$ & $\begin{array}{l}-0.149 \\
(0.290)\end{array}$ & $\begin{array}{l}-0.270 \\
(0.192)\end{array}$ \\
\hline Affiliate size (logged assets) & $\begin{array}{c}0.533 \\
(0.323)\end{array}$ & $\begin{array}{c}0.574 \\
(0.370)\end{array}$ & $\begin{array}{c}0.200 \\
(0.422)\end{array}$ & $\begin{array}{l}0.724^{* *} \\
(0.328)\end{array}$ & $\begin{array}{c}0.367 \\
(0.257)\end{array}$ & $\begin{array}{c}0.435 \\
(0.337)\end{array}$ & $\begin{array}{c}0.549 \\
(0.338)\end{array}$ & $\begin{array}{c}0.165 \\
(0.386)\end{array}$ & $\begin{array}{c}0.735^{* *} \\
(0.340)\end{array}$ & $\begin{array}{l}0.358^{*} \\
(0.215)\end{array}$ \\
\hline Affiliate age & $\begin{array}{c}-0.012^{* *} \\
(0.006)\end{array}$ & $\begin{array}{l}-0.006 \\
(0.005)\end{array}$ & $\begin{array}{l}-0.010 \\
(0.006)\end{array}$ & $\begin{array}{l}-0.007 \\
(0.006)\end{array}$ & $\begin{array}{l}-0.004 \\
(0.003)\end{array}$ & $\begin{array}{c}-0.013^{* * *} \\
(0.003)\end{array}$ & $\begin{array}{l}-0.007^{*} \\
(0.004)\end{array}$ & $\begin{array}{c}-0.011^{* *} \\
(0.005)\end{array}$ & $\begin{array}{l}-0.009 \\
(0.005)\end{array}$ & $\begin{array}{l}-0.004 \\
(0.004)\end{array}$ \\
\hline Group size (logged assets) & $\begin{array}{l}-0.506 \\
(0.357)\end{array}$ & $\begin{array}{c}-0.546 \\
(0.387)\end{array}$ & $\begin{array}{l}-0.193 \\
(0.458)\end{array}$ & $\begin{array}{l}-0.665^{*} \\
(0.361)\end{array}$ & $\begin{array}{l}-0.266 \\
(0.272)\end{array}$ & $\begin{array}{c}-0.429 \\
(0.356)\end{array}$ & $-0.534(0.354)$ & $\begin{array}{l}-0.171 \\
(0.406)\end{array}$ & $\begin{array}{l}-0.677^{*} \\
(0.352)\end{array}$ & $\begin{array}{l}-0.257 \\
(0.225)\end{array}$ \\
\hline Group return-on-assets & $\begin{array}{c}0.051^{* * *} \\
(0.014)\end{array}$ & $\begin{array}{c}0.051^{* * *} \\
(0.017)\end{array}$ & $\begin{array}{l}0.059^{* *} \\
(0.023)\end{array}$ & $\begin{array}{c}0.052^{* * *} \\
(0.013)\end{array}$ & $\begin{array}{c}0.033^{* * *} \\
(0.010)\end{array}$ & $\begin{array}{c}0.053^{* * *} \\
(0.010)\end{array}$ & $\begin{array}{c}0.055^{* * *} \\
(0.009)\end{array}$ & $\begin{array}{c}0.060^{* * *} \\
(0.011)\end{array}$ & $\begin{array}{c}0.054^{* * *} \\
(0.009)\end{array}$ & $\begin{array}{c}0.033^{* * *} \\
(0.006)\end{array}$ \\
\hline Group Liability & $\begin{array}{l}-0.001 \\
(0.053)\end{array}$ & $\begin{array}{l}-0.037 \\
(0.065)\end{array}$ & $\begin{array}{l}-0.062 \\
(0.077)\end{array}$ & $\begin{array}{c}0.005 \\
(0.048)\end{array}$ & $\begin{array}{c}0.061 \\
(0.043)\end{array}$ & $\begin{array}{c}0.020 \\
(0.070)\end{array}$ & $\begin{array}{l}-0.008 \\
(0.075)\end{array}$ & $\begin{array}{l}-0.045 \\
(0.083)\end{array}$ & $\begin{array}{l}-0.031 \\
(0.065)\end{array}$ & $\begin{array}{c}0.062 \\
(0.046)\end{array}$ \\
\hline Equity centrality & & & & $\begin{array}{l}-0.137 \\
(0.247)\end{array}$ & $\begin{array}{c}0.253 \\
(0.162)\end{array}$ & & & & $-0.091(0.240)$ & $\begin{array}{c}0.251 \\
(0.160)\end{array}$ \\
\hline Innovative capability*Operating density & $\begin{array}{c}0.491 * * * \\
(0.147)\end{array}$ & & & $\begin{array}{l}0.351^{*} \\
(0.186)\end{array}$ & $\begin{array}{l}0.336^{*} \\
(0.170)\end{array}$ & $\begin{array}{c}0.502^{* * *} \\
(0.083)\end{array}$ & & & $\begin{array}{c}0.315 * * * \\
(0.105)\end{array}$ & $\begin{array}{c}0.335^{* * *} \\
(0.070)\end{array}$ \\
\hline Innovative capability*Equity density & & $\begin{array}{c}0.535^{* * *} \\
(0.119)\end{array}$ & & $\begin{array}{l}0.246^{* *} \\
(0.112)\end{array}$ & $\begin{array}{c}0.231^{* * *} \\
(0.078)\end{array}$ & & $\begin{array}{c}0.559^{* * *} \\
(0.090)\end{array}$ & & $\begin{array}{c}0.316^{* * *} \\
(0.118)\end{array}$ & $\begin{array}{c}0.231^{* * *} \\
(0.080)\end{array}$ \\
\hline Innovative capability*Director density & & & $\begin{array}{c}0.120 \\
(0.146)\end{array}$ & $\begin{array}{l}-0.074 \\
(0.140)\end{array}$ & $\begin{array}{l}-0.099 \\
(0.083)\end{array}$ & & & $\begin{array}{c}0.137 \\
(0.119)\end{array}$ & $\begin{array}{l}-0.070 \\
(0.101)\end{array}$ & $\begin{array}{l}-0.097 \\
(0.066)\end{array}$ \\
\hline Constant & $\begin{array}{c}-10.353^{* *} \\
(4.468)\end{array}$ & $\begin{array}{c}-8.810^{* *} \\
(3.759)\end{array}$ & $\begin{array}{l}-5.572^{*} \\
(2.875)\end{array}$ & $\begin{array}{c}-10.204^{* *} \\
(4.810)\end{array}$ & $\begin{array}{c}-25.242^{* * *} \\
(3.479)\end{array}$ & $\begin{array}{c}-10.089 * * * \\
(2.503)\end{array}$ & $\begin{array}{c}-8.286 * * * \\
(2.393)\end{array}$ & $\begin{array}{c}-5.858^{* *} \\
(2.873)\end{array}$ & $\begin{array}{c}-9.815^{* * *} \\
(2.405)\end{array}$ & $\begin{array}{c}-25.244 * * * \\
(2.137)\end{array}$ \\
\hline$R$-square & $64.10 \%$ & $62.96 \% \%$ & $50.46 \%$ & $67.39 \%$ & $86.40 \%$ & N.A. & N.A. & N.A. & N.A. & N.A. \\
\hline Number of observations & 100 & 100 & 100 & 100 & 100 & 100 & 100 & 100 & 100 & 100 \\
\hline
\end{tabular}

*** Significant at $1 \%$ level; ** significant at $5 \%$ level; * significant at $10 \%$ level. Standard errors are in the parentheses; Dummy variables for industry are included in the models.

of Table 2, and Model 5 and Model 10 of Table 3 suggest that our results are robust to this argument.

Finally, we use a flexible random effects method known as the Generalized Estimating Equations (GEE) for panel data (Liang and Zeger 1986). A useful feature of the GEE approach for panel data estimation is that it does not require the observations for all subjects to have the same correlation structure. Instead, GEE allows us to specify within-group correlation structures, as well as correct for heteroskedasticity. The right half of Tables 2 and 3 indicates that our results are materially unchanged when GEE is used to control for within group correlations across multiple years as well as for heteroskedasticity

\section{Discussion}

This study offers important implications for firm capability and social network research. For firm capability research, the study suggests the need to examine the value of capabilities when firms are embedded in a variety of formal and informal relationships. Existing strategy research employing the resource-based view of the firm explains variations in firm performance as primarily arising from firms' own capabilities (Barney, 1991). Our research, 
however, challenges this assertion by highlighting the effects of firms' network ties on the value of their own capabilities. Rather than operating independently, firms are intertwined with each other through network ties. Consequently, the formal and informal ties connecting a focal firm to other firms may appreciate or depreciate the value of the focal firm's capabilities, depending on the structure of the network, as well as the type of network ties in which the firm is embedded. We find that a firm's innovative capability is generally more valuable in a network with dense network ties than in one with scant network ties. This is because the rich information and ideas transferred through network ties stimulate the growth of innovative capability. However, this effect is contingent on the type of network ties. Buyer-supplier ties and equity ties significantly appreciate the value of innovative capability, but directorship ties do not have any impact.

This study contributes to the network literature by incorporating firm capabilities into the analytical framework of how social networks affect the exploitation of firm capabilities, and thus firm performance. Extant network literature points out that network density and a firm's location in a network significantly impact firm value. They also discuss how networks lead to firm capability (McEvily and Zaheer, 1999; Mahmood et al., 2011). However, little is known as to how the attributes of networks, such as the type of network ties and the overall structure of the network, influence the embedded firms' capabilities, and thus firm value. We explore this question and find that network density does impact firm capability, and that this influence differs by the type of ties. Specifically, the value of innovative capability increases with operating density and equity density, while it is not affected by directorship density.

By clarifying the interface between firm capability and business group networks, this study also provides some managerial guidance to business group managers. The positive interactive effects between firm innovative capability and operating density and equity density suggest that in order to achieve higher profitability by exploiting their innovative capability, affiliates should engage in maintaining these two types of ties with other group members.

Besides the theoretical contributions, this study also contributes empirically by modeling firm-specific capabilities, thus separating out the effects of the resources owned by an affiliate from the effects of the resources owned by the group on the performance of individual affiliates. Such new measures of firm-specific effects enable us to accurately identify the effect of intra-group networks in a business group. The overall results suggest that intra-group network ties are an important channel through which business groups affect the profitability of their group members. Groups are efficient in the sense that their internal networks minimize the transaction costs resulting from market imperfections prevalent in emerging economies and promote information exchange and resource sharing, which are hard to 
achieve via the market system (Khanna and Palepu, 1997).

\section{Limitations and Directions for Future Research}

A potential limitation of this study is that the business group network may not be representative of other types of interfirm networks. Examining the interplay between firm capability and network structure in other types of interorganizational networks may help address the question of external validity. Moreover, our empirical context is an emerging economy, Taiwan. A multi-country analysis incorporating institutional differences could help to evaluate the robustness of the results to other institutional contexts.

The study offers several avenues for further research. First, it would be interesting to investigate how intra-group network ties will evolve as the institutional environments of emerging economies improve. Intra-group ties create value for group affiliates by promoting their resource sharing, information exchange, and thus exploitation of innovative capability. Future research may examine whether such benefits will mitigate as market intermediaries develop and whether this in turn makes intra-group networks sparse. Second, just as we have shown that different types of ties play distinct roles in shaping the value of firm capabilities, others might study whether and how the efficacy of each type of ties will change as a result of institutional transition and market development of emerging economies. This will provide implications as to what types of ties business groups should construct and maintain among the multiplex relationships intertwining member firms in response to the changing environment. Third, more disaggregated measures of firm capability, which go beyond functional domains and focuses on individual projects (Ethiraj et al., 2005; Henderson and Cockburn, 1994), may be useful for unmasking the mechanisms by which group-level resource sharing benefits affiliates' performance. Second, just as capabilities affect firm performance, the latter also has an impact on the former, making it difficult to establish causality. The huge windfall generated from Samsung's DRAM units in the early 1990s, for example, allowed Samsung to make significant investments in furthering its innovative capabilities. In this study, we addressed this issue of causality by considering multiple contingencies that provided the boundary conditions for the underlying theoretical mechanisms by which firm capability influences performance. Examining the simultaneous relationship between capabilities and performance may be a useful next step. Finally, as Dutta and his colleagues lament, "As far as limitations go, the most obvious one is the use of a parametric approach to estimating capabilities." One promising alternative is to use semiparametric methods based on a combination of Stochastic Frontier Estimation (SFE) and Data Envelopment Analysis (DEA). Such extensions would continue the task of unpacking the black box of networks and firm capabilities. 


\section{References}

Ahuja, G., 2000. Collaboration Networks, Structural holes, and Innovation: A Longitudinal Study. Administrative Science Quarterly 45, 425-455. doi:10.2307/2667105

Amit, R., Shoemaker, J., 1993. Strategic Assets and Organizational Rent. Strategic Management Journal 14, 33-46. doi:10.1002/smj.4250140105

Amsden, H., Chu, W., 2003. Beyond Late Development: Taiwan's Upgrading Policies. The MIT Press, Cambridge, MA.

Amsden, A., Hikino, T., 1994. Project Execution Capability, Organizational Know-how and Conglomerate Corporate Growth in Late Industrialization. Industrial and Corporate Change 3, 111-147. doi:10.1093/icc/3.1.111

Barney, J., 1991. Firm Resources and Sustained Competitive Advantage. Journal of Management 17, 99-120. doi:10.1177/014920639101700108

Burt, R., 1992. Structural Holes: The Social Structure of Competition. Cambridge, Mass.: Harvard University Press.

Burt, R., 2000. The Network Structure of Social Capital. In: Robert, I., Barry, M. (Eds.), Research in Organizational Behavior. Greenwich, CT: JAI Press.

Chang, S.J., Hong, J., 2000. Economic Performance of the Korean Business Groups: Intra-group Resource Sharing and Internal Business Transaction. Academy of Management Journal 43, 429-448. doi:10.2307/1556403

Chintagunta, P.K., Jain, D C., Vilcassim, N.J., 1993. Investigating Heterogeneity in Brand Preference in Logit Models for Panel Data. Journal of Marketing Research 28, 217-228.

Chung, C.N., 2003. Managerial Structure of Business Groups in Taiwan: The Inner Circle System and Its Social Organization. Developing Economies 41, 37-64. doi:10.1111/j.1746-1049.2003.tb00929.x

Claessens, S., Simeon, D., Lang, H.P., 2000. The Separation of Ownership and Control in East Asian Corporations. Journal of Financial Economics 52, 81-112. doi:10.1016/S0304-405X(00)00067-2

Cohen, W.M., Levinthal, D., 1990. Absorptive Capacity: A New Perspective on Learning and Innovation. Administrative Science Quarterly 35, 128-152. doi: $10.2307 / 2393553$

Coleman, J.S., 1988. Social Capital in the Creation of Human Capital. American Journal of Sociology 94, 95-120. doi:10.1086/228943 
Coleman, J.S., 1990. Foundations of Social Theory. Cambridge, MA: Harvard University Press.

Dutta, S., Narasimhan, O., Rajiv, S., 2005. Conceptualizing and Measuring Capabilities: Methodology and Empirical Application. Strategic Management Journal 26, 277-285. Dutta, S., Narasimhan, O., Rajiv, S., 1999. Success in High-technology Markets: Is Marketing Capability Critical? Marketing Science 18, 547-568. doi:10.1287/mksc.18.4.547

Dyer, J.H., Nobeoka, K., 2000. Creating and Managing a High-performance Knowledge-sharing Network: The Toyota Case. Strategic Management Journal 21, 345-367. doi:10.1002/(SICI)1097-0266(200003)21:3<345::AIDSMJ96 $>3.0 . \mathrm{CO} ; 2-\mathrm{N}$

Eisenhardt, K.M., Martin, J.A., 2000. Dynamic Capabilities: What are they? Strategic Management Journal 21, 1105-1121. doi:10.1002/10970266(200010/11)21:10/11<1105::AID-SMJ133>3.0.CO;2-E

Ethiraj, S., Kale, P., Krishnan, M.S., Singh, J., 2005. Where Do Capabilities Come from and How Do They Matter? A Study in the Software Services Industry. Strategic Management Journal 26, 25-45. doi:10.1002/smj.433

Fleming, L., 2001. Recombinant Uncertainty in Technological Search. Management Science 47, 117-132. doi:10.1287/mnsc.47.1.117.10671

Fukuyama, F., 1995. Trust: The Social Virtues and the Creation of Prosperity. New York: Free Press.

Freeman, L.C., 1977. A Set of Measures of Centrality Based on Betweenness. Sociometry 40, 35-41. doi:10.2307/3033543

Gnyawali, D.R., Madhavan, R., 2001. Cooperative Networks and Competitive Dynamics: A Structural Embeddedness Perspective. Academy of Management Review 26, 431-445.

Granovetter, M., 1985. Economic Action and Social Structure: The Problem of Embeddedness. American Journal of Sociology 91, 481-510. doi:10.1086/228311

Granovetter, M., 1995. Coase Revisited: Business Groups in the Modern Economy. Industrial and Corporate Change 4, 93-140. Gulati, R., 1999. Network Location and Learning: The Influences of Network Resources and Firm Capabilities on Alliance Formation. Strategic Management Journal 20, 397-420.

Gulati, R., Westphal, J.D., 1999. Cooperative or Controlling? The Effects of CEO-board Relations and the Content of Interlocks on the Formation of Joint Ventures. Administrative Science Quarterly 44, 473-506. doi:10.2307/2666959 
Hamilton, G.G., Biggart, N.W., 1988. Market, Culture, and Authority: A Comparative Analysis of Management and Organization in the Far East. American Journal of Sociology 94, 52-94. doi:10.1086/228942

Hamilton, G.G., Kao, C.H., 1990. The Institutional Foundation of Chinese Business: The Family Firm in Taiwan. In: Calhoun, C. (Eds.), Comparative Social Research, JAI Greenwich, pp. 135-151.

Hamilton, G.G., 1997. Organization and Market Processes in Taiwan's Capitalist Economy. In: Marco, O., Biggart, N.W., Hamilton, G. G. (Eds.), The Economic Organization of East Asian Capitalism, Thousand Oaks, California: Sage, pp. 237-293.

Hargadon, A., Sutton, R.I., 1997. Technology Brokering and Innovation in A Product Development Firm. Administrative Science Quarterly 42, 716-749. doi:10.2307/2393655

Henderson, R., Cockbum, I., 1994. Measuring Competence? Exploring Firm Effects in Pharmaceutical Research. Strategic Management Journal 15, 6375. doi:10.1002/smj.4250150906

Hobday, M., 1995. Innovation in East Asia. Edward Elgar Publishing Ltd., Hants, England.

Khanna, T., Palepu, K., 1997. Why Focused Strategies May Be Wrong for Emerging Markets. Harvard Business Review 75, 41-51.

Khanna, T., Palepu, K., 2000. Is Group Affiliation Profitable in Emerging Markets? An Analysis of Diversified Indian Business Groups. Journal of Finance 55, 867-891. doi:10.1111/0022-1082.00229

Khanna, T., Rivkin, J., 2001. Estimating the Performance Effects of Business Groups in Emerging Markets. Strategic Management Journal 22, 4574. doi:10.1002/1097-0266(200101)22:1<45::AID-SMJ147>3.0.CO;2-F

La Porta, R., Lopez-de-Silanes, F., Shleifer, A., 1999. Corporate Ownership around the World. Journal of Finance 54, 471-517. doi:10.1111/00221082.00115

La Porta, R., Shleifer, A., Vishny, R.W., 1997. Legal Determinants of External Finance. Journal of Finance 52, 1131-1150. doi:10.1111/j.15406261.1997.tb02727.x

Liang, K.Y., Zeger, S.L., 1986. Longitudinal Data Analysis using Generalized Linear Models. Biometrika 73, 13-22. doi:10.1093/biomet/73.1.13

Lincoln, J.R., Gerlach, M.L., Takahashi, P., 1992. Keiretsu Networks and Corporate Performance in Japan. American Sociological Review 61, 67-88. doi:10.2307/2096407 
Luo, X.W., Chung, C.N., 2005. Keeping It All in the Family: The Role of Particularistic Relationships in Business Group Performance during Institutional Transition. Administrative Science Quarterly 50, 404-439. doi:10.2189/asqu.2005.50.3.404

Mahmood, I.P., Zhu, H., Zajac, E., 2011. Where Can Capabilities Come from? Network Ties and Capability acquisition in Business Groups. Strategic Management Journal 32, 820-848. doi:10.1002/smj.911

Makadok, R., 2001. Toward A Synthesis of the Resource-based and Dynamic-capability Views of Rent Creation. Strategic Management Journal 22, 387-402. doi:10.1002/smj.158

McEvily, B., Marcus, A., 2005. Embeddedness and the Acquisition of Competitive Capabilities. Strategic Management Journal 26, 1033-1055. doi:10.1002/smj.484

McEvily, B., Zaheer, A., 1999. Bridging Ties: A Source of Firm Heterogeneity in Competitive Capabilities. Strategic Management Journal 20, 1133-1156. doi:10.1002/(SICI)1097-0266(199912)20:12<1133::AID-SMJ74>3.0.CO;2-7

Morck, R., Yeung, B., 2004. Family-control and the Rent-seeking society. Entrepreneurship Theory and Practice 28, 391-409. doi:10.1111/j.15406520.2004.00053.x

Nahapiet, J., Ghoshal, S., 1998. Social Capital, Intellectual Capital, and the Organizational Advantage. Academy of Management Review 23, 242-266.

Nelson, R.R, Winter, S.G., 1982. An Evolutionary Theory of Economic Change. Cambridge, Mass: Harvard University Press.

Nohria, N., Eccles, R., 1992. Face-to-face: Making Network Organizations Work. In: Nohria, N., Eccles, R., (Eds). Networks and Organizations: Structure, Form and Action, Boston: Harvard Business School Press, pp. 288308.

Numazaki, I., 1986. Networks of Taiwanese Big Business: A Preliminary Analysis. Modern China 12, 487-534. doi:10.1177/009770048601200403

Peteraf, M., 1993. The Cornerstones of Competitive Advantage: A Resource-based View. Strategic Management Journal 14, 179-191. doi:10.1002/smj.4250140303

Podolny, J., Baron, J., 1997. Resources and Relationships: Social Networks and Mobility in the Workplace. American Sociological Review 62, 673-93. doi: $10.2307 / 2657354$ 
Powell, W.W., Smith-Doerr, L., 1994. Networks and Economic Life. In: Smelser, N. J., Swedberg, R. (Eds), The Handbook of Economic Sociology, Princeton, NJ: Princeton University Press, pp. 368-402.

Saxonhouse, G.R., 1993. What does Japanese Trade Structure Tell Us about Japanese Trade Policy? Journal of Economic Perspectives 7, 21-43 doi:10.1257/jep.7.3.21

Schumpeter, J.A., 1934. The Theory of Economic Development. Cambridge: Harvard University Press.

Teece, D.J., 1989. Inter-organizational Requirements of the Innovation Process. Managerial and Decision Economics (Special Issue), 35-42.

Teece, D.J., Pisano, G.P., 1994. The Dynamic Capabilities of Firms: An Introduction. Industrial and Corporate Change 3, 537-556. doi:10.1093/icc/3.3.537-a

Treacy, M., Wiersema, F., 1993. Customer Intimacy and Other Value Disciplines. Harvard Business Review (January-February), 84-93. Tsai, W., 2001. Knowledge Transfer in Intraorganizational Networks: Effects of Network Position and Absorptive Capacity on Business Unit Innovation and Performance. Academy of Management Journal 44, 996-1004.

Uzzi, B., 1997. Social Structure and Competition in Interfirm Networks: The Paradox of Embeddedness. Administrative Science Quarterly 42, 35-67. doi:10.2307/2393808

Van Zandt, T., 2004. Information Overload in A Network of Targeted Communication. Rand Journal of Economics 35, 542-560. von Hippel, E., 1989. New Product Ideas from "Lead Users". Research Management 32, 24-27. Weinstein, D.E, Yafeh, Y., 1995. Japan's Corporate Groups: Collusive or Competitive? An Empirical Investigation of Keiretsu Behavior. Journal of Industrial Economics 43, 359-376.

Weitzman, M., 1998. Recombinant Growth. Quarterly Journal of Economics 113, 331-360. doi:10.1162/003355398555595

Wernerfelt, B., 1984. A Resource-based View of the Firm. Strategic Management Journal 5, 171-180. doi:10.1002/smj.4250050207

Williamson, O.E., 1985. The Economic Institutions of Capitalism: Firms, Markets, Relational Contracting. New York: The Free Press.

Zaheer, A., Bell, G.G., 2005. Benefiting from Network Position: Firm Capabilities, Structural Holes, and Performance. Strategic Management Journal 26, 809-825. doi:10.1002/smj.482 
Zaheer, A., Venkatraman, N., 1995. Relational Governance as An Interorganizational Strategy: An Empirical Test of the Role of Trust in Economic Exchange. Strategic Management Journal 16, 373-392. doi:10.1002/smj.4250160504 


\section{Appendix 1}

Modeling innovative capability. We define a firm's innovative capability as its ability to allocate resources to achieve the maximum level of technological output given a certain level of deployed resources. Resources that influence technological output (TECHOUTPUT) include a firm's technological base (TECHBASE) and its accumulated R\&D expenditure (CUM_R\&DEXPENSE) (Dutta et al., 1999). Using a Cobb-Douglas production function, we specify the innovation frontier as follows:

$$
\begin{aligned}
\ln (\text { TECHOUTPUT })= & \beta_{0}+\beta_{1} \ln \left(T E C H B A S E_{i t}\right)+ \\
& \beta_{2} C U M_{-} R \& D E X P E N S E_{i t}+v_{i t}-u_{i t}
\end{aligned}
$$

We use the number of successful Taiwanese local patent applications to measure a firm's technological output (TECHOUTPUT).$^{5}$ U.S. patents are used as a robustness check, with the results being qualitatively similar. As R\&D expenditures are likely to have a lagged impact on patent application, we use a two-year lag with respect to the dates of R\&D expenditures. For robustness purpose, we experiment with concurrent and three-year lag structures. The results are very similar.

Technological base (TECHBASE) is defined as the stock of technological output, with a lower weight on the technological output in earlier years than in later years. Specifically, technological base results from the estimation of a Koyck lag function on technological output. Technological base for period $t$ is specified as

$$
\text { TECHBASE } E_{t}=\sum_{k=1}^{t} \delta^{t-k} \text { TECHOUTPUT },
$$

where $t=1, \ldots, 5$ periods. Here parameter $\delta$ indicates the weight assigned to the technological output in previous years. The higher the value of $\delta$, the greater the spillover effect from past levels of technological output.

Accumulated RED expenditure (CUM REDEXPENSE) is defined as the stock of R\&D expenditures, with lower weights on earlier R\&D expenditures than on later R\&D expenditures in a Koyck lag structure. Specifically, the accumulated $R \& D$ expenditure for period $t$ is specified as

$$
C U M_{-} R \& D E X P E N S E_{t}=\sum_{k=1}^{t} \delta^{t-k} R D E X P E N S E_{k},
$$

\footnotetext{
5 This measure treats all patents as equally important. We recognize that a better approach would be to use quality-adjusted patent counts, which assign a weight to a firm's patent based on the number of citations the patent has received (Dutta et al, 1999). Due to the unavailability of patent citation information for local patents, we use raw patent counts as a measure of technological output.
} 
where $t=1, \ldots, 5$ periods. Here $\gamma$ is the weight assigned to R\&D expenditures in previous periods. The higher the value of $\gamma$, the greater the spillover effect from R\&D expenditures in previous periods. We expect both $\beta_{1}$ and $\beta_{2}$ to be positive.

Modeling marketing capability. We defined the marketing capability of a firm as its ability to allocate resources to achieve the maximum level of sales given a certain level of its resources. Such determinant resources to sales include technological base (TECHBASE), marketing expenditure (MARKETINGSTOCK), advertising expenditure (ADVSTOCK), and instal-led base of customers (Dutta et al., 1999). Again, we adopt the CobbDouglas production function and specify the sales frontier as follows:

$$
\begin{aligned}
& \ln \left(\text { Sales }_{i t}\right)=\alpha_{0}+\sum_{k=1}^{19} \alpha_{k} \text { Industry }_{i t k}+\alpha_{20} \ln \left(\text { ADSTOCK }_{i t}\right)+ \\
&+\alpha_{21} \ln \left(\text { MARKSTOCK }_{i t}\right)+\alpha_{22} \ln \left(\text { TECHBASE }_{i t}\right)+ \\
&+\alpha_{23} \ln (\text { INSTALLEDBASE } \\
&i t)+v_{i t}-u_{i t}
\end{aligned}
$$

Modeling manufacturing capability. A firm's manufacturing capability is defined as its ability to deploy its resources efficiently to achieve the minimum level of cost of production, given a certain level of resources input. Resources related to the cost of production include output (OUTPUT), labor cost (LABORCOST), and the technological base (TECHBASE) (Dutta et al., 1999). Once again, we use a Cobb-Douglas production function and specify the cost frontier as follows:

$$
\begin{aligned}
\ln \left(C_{C O S T_{i t}}\right) & =\gamma_{0}+\gamma_{1} \ln \left(O U T P U T_{i t}\right)+\gamma_{2} \ln \left(\text { LABCOST }_{i t}\right)+ \\
& +\gamma_{3} \ln \left(\text { TECHBASE } E_{i t}\right)+v_{i t}-u_{i t}
\end{aligned}
$$




\section{Appendix 2}

Table A1 - Measuring Innovative Capability Using Random Parameters Stochastic Frontier Model

\begin{tabular}{lcc}
\hline \multicolumn{1}{c}{ Variables } & Population Average Effect & $\begin{array}{c}\text { Variance of Unobserved } \\
\text { Heterogeneity Component }\end{array}$ \\
\hline$\hat{\beta}_{1}[\ln ($ TECHBASE)] & $0.550^{* * *}$ & $0.021^{* * *}$ \\
$\hat{\beta}_{2}[\ln ($ CUM_R\&DEXPENSE)] & $(0.135)$ & $0.006)$ \\
Composite Error Variance $\left(\delta_{e}{ }^{2}=\delta_{v}{ }^{2}+\delta_{u}{ }^{2}\right)$ & $0.195^{* *}$ & $(0.002)$ \\
& $(0.024)$ & \\
Variance of Inefficiency Error Term $\left(\delta_{u}{ }^{2}\right)$ & $1.786^{* *}$ & \\
& $1.032)$ & \\
Log-likelihood Function & $(0.018)$ & \\
\hline \hline
\end{tabular}

*** Significant at $1 \%$ level; ** significant at $5 \%$ level; * significant at $10 \%$ level. Standard errors are in the parentheses. The likelihood ratio test is used to test the overall significance of the model.

Table A2 - Measuring Marketing Capability Using Random Parameters Stochastic Frontier Model

\begin{tabular}{lcc}
\hline \multicolumn{1}{c}{ Variables } & Population Average Effect & $\begin{array}{c}\text { Variance of Unobserved } \\
\text { Heterogeneity Component }\end{array}$ \\
\hline$\hat{\alpha}_{20}[\ln ($ ADSTOCK $)]$ & $0.523^{* * *}$ & $0.193^{* *}$ \\
$\hat{\alpha}_{21}[\ln (\mathrm{MARKSTOCK})]$ & $(0.039)$ & $(0.009)$ \\
$\hat{\alpha}_{22}[\ln ($ TECHBASE) $]$ & $0.897^{* * *}$ & 0.128 \\
$\hat{\alpha}_{23}[\ln ($ INSTALLEDBASE) $]$ & $(0.004)$ & $(0.122)$ \\
& $0.428^{* * *}$ & $0.142^{*}$ \\
Composite error variance $\left({ }_{e}{ }^{2}=\delta_{v}{ }^{2}+\delta_{u}{ }^{2}\right)$ & $(0.003)$ & $(0.047)$ \\
Variance of Inefficiency Error Term $\left({ }^{2}{ }^{2}\right)$ & $0.615^{* * *}$ & $0.467^{* *}$ \\
Log-likelihood Function & $(0.012)$ & $(0.018)$ \\
\hline \hline
\end{tabular}

*** Significant at $1 \%$ level; ** significant at $5 \%$ level; * significant at $10 \%$ level. Standard errors are in the parentheses. The likelihood ratio test is used to test the overall significance of the model. 
Table A3 - Measuring Manufacturing Capability Using Random Parameters Stochastic Frontier Model

\begin{tabular}{lcc}
\hline \multicolumn{1}{c}{ Variables } & Population Average Effect & $\begin{array}{c}\text { Variance of Unobserved } \\
\text { Heterogeneity Component }\end{array}$ \\
\hline$\hat{\gamma}_{1}[\ln ($ OUTPUT) $]$ & $0.761^{* * *}$ & $0.048^{* * *}$ \\
$\hat{\gamma}_{2}[\ln ($ LABORCOST)] & $(0.004)$ & $(0.001)$ \\
$\hat{\gamma}_{3}[\ln ($ TECHBASE) $]$ & $0.186^{* * *}$ & $0.025^{* *}$ \\
& $(0.013)$ & $(0.012)$ \\
Composite error variance $\left({ }^{2}{ }^{2}=\delta_{v}{ }^{2}+\delta_{u}{ }^{2}\right)$ & $-0.163^{* * *}$ & $0.107^{* *}$ \\
& $(0.007)$ & $(0.074)$ \\
Variance of Inefficiency Error Term $\left({ }^{2}{ }^{2}{ }^{2}\right)$ & $1.934^{* * *}$ & \\
Log-likelihood Function & $(0.101)$ & \\
\hline \hline
\end{tabular}

*** Significant at $1 \%$ level; ${ }^{* *}$ significant at $5 \%$ level; ${ }^{*}$ significant at $10 \%$ level. Standard errors are in the parentheses. The likelihood ratio test is used to test the overall significance of the model. 